\title{
Támogatni vagy nem támogatni? Filmtámogatási rendszerek kritikai megközelítése: az amerikai és az európai modell
}

\author{
állami támogatás - filmipar - támogatási verseny - Európai Unió - \\ Egyesült Államok
}

\begin{abstract}
Jelen tanulmány célja, hogy a filmtámogatási rendszerek eredetét ismertesse, összehasonlítva az amerikai és európai fejlődés eltérő mozgatórugóit, amelyek az egyre erősödő filmtámogatási verseny globalizációjához vezettek. Az Európai Unió szabályai a filmgyártás területén az Európai Unió Működéséről Szóló Szerződés (EUMSZ) állami támogatási szabályait szabályozó cikkeinek fényében, valamint az Európai Bizottság Filmművészeti Közleménye támogatási szabályainak figyelembevételével kerültek rögzítésre.

A tagállami filmtámogatási rendszerek uniós jogi megfelelőségi vizsgálata nem képezi a jelen tanulmány tárgyát. Így itt nem kívánok áttekintést adni az uniós joggyakorlatról, a Bizottság filmtámogatási programokat vizsgáló tevékenységéről sem, amelyet egy másik tanulmányban kívánok feldolgozni. ${ }^{1}$
\end{abstract}

\section{A filmtámogatási rendszerek eredete, filmes adókedvezmények az Egyesült Államokban és Európában}

A filmgyártás kettős, kulturális és gazdasági természetéből adódóan a filmtámogatási rendszerek létrehozásában kulturális és gazdasági indokok is szerepet játszhatnak. Az elmúlt évtizedekben felerősödő verseny - elsősorban az amerikai nagyprodukciók helyszínre vonzásáért - különféle adókedvezmények formáját öltötte, hogy a produkciókban rejlő gazdasági előnyöket, mint amilyen a munkalehetőség vagy befektetések, egy adott ország területére vonzza.

Az Egyesült Államokkal szemben, ahol a filmgyártás elsődlegesen piaci alapon nyugszik, Európában - mindenekelött Franciaországban - nagy hagyománya van a nemzeti filmgyártás kulturális célú állami támogatásának. Olyannyira, hogy mára az

* Dr. Szalay Klára vezető tanácsos, Országgyűlés Hivatala, Budapest, klaraszalay@hotmail.com. A tanulmány egy hosszabb terjedelmű munka része. A szövegben szereplö állítások nem tükrözik a hivatal álláspontját, azokért kizárólag a szerző felelős.

1 Abban tervezem ismertetni többek között a magyar filmtámogatási rendszert is, összehasonlítva az Egyesült Királyság filmtámogatási programjával, valamint kitérve olyan nehézségek elemzésére, mint a kultúra mérhetőségének kérdésköre, illetve az EU kulturális politikai hatáskörével kapcsolatos jogi kérdések elemzése. Ezek tehát nem képezik jelen tanulmány tárgyát. 
európai filmgyártás jelentős mértékben elszakadt a piaci folyamatoktól. Az amerikai filmgyártástól való eltérést jól példázza, hogy az évezredfordulón egy Európában készült film átlagos költsége 500000 euró volt, melyet 70-80\%-ban állami finanszírozásból teremtettek elő, mintegy 800000 euró bevételt hozott és 150000 fös nézöközönséget vonzott. Ezzel szemben egy átlagos amerikai film költsége 15 millió euró volt, majdnem 100\%-ban befektetői finanszírozással jött létre, 58 millió eurós bevételt hozott és világszerte 10,5 millióan látták. ${ }^{2}$ Bár a nemzeti és európai szintű támogatási rendszerek hatására az európai filmek száma évről évre nő (2005 és 2009 között 28\%-os volt a növekedés), ${ }^{3}$ az amerikai filmgyártás gazdasági fölénye nem csökken (2010-re elérte a 68\%-os piaci részesedést Európában). ${ }^{4}$

Az amerikai filmgyártás fölényével szembeni védekezés igénye az európai filmpolitikát kezdettől fogva meghatározta. Már az 1920-as években megjelentek olyan protekcionista eszközök (például vetítési kvóták, extra adók a bemutatott amerikai filmek után), amelyekkel az egyes országok saját filmiparukat próbálták védeni az amerikai filmekkel szemben. Ebböl a nézőpontból úttörönek számított Németország (1921), az Egyesült Királyság (1927), Olaszország (1927) és Magyarország (1925 és 1929) is. ${ }^{5}$ A valódi értelemben vett filmtámogatási rendszerek azonban a II. világháború után bontakoztak ki, változatos formában. ${ }^{6} \mathrm{Az}$ első támogatási formák közé tartoztak a kedvezményes hitelek (Franciaország, 1941), a hitelgaranciák (Németország, 1952), és a különböző adóbevételekre ${ }^{7}$ épülö, azokat a jegybevételek arányában felosztó automatikus támogatási rendszerek (Franciaország, 1948;8 Egyesült Királyság, „Eady Levy”, 1950; Belgium, 1952). ${ }^{9}$ Ez utóbbi, azaz az automatikus támogatási rendszer kritikájaként jelent meg első ízben Franciaországban, 1953-ban a minőség kritériuma a rövidfilmek támogatása során, amelyet hamarosan (1955-ben) a nagyjátékfilmekre is kiterjesztettek. Ezzel vette kezdetét a kulturális alapú, szelektív támogatások európai hagyománya, amely eleinte az újitó törekvé-

2 A bruttó nyereséget tekintve az európai $60 \%$ áll szemben az amerikai $287 \%$-os nyereséggel. Az egy nézöre vetített költség tekintetében 3,33 áll az 1,43 euróval szemben, az egy nézöre vetített árbevétel 5,30 szemben 5,52 euróval. BAKKER, Gerben: The Economic History of the International Film Industry. Whaples, Robert (ed.): EH.Net Encyclopedia. http://eh.net/encyclopedia/the-economic-history-of-the-internationalfilm-industryl (2015. 10. 06.).

3 Gubins, Michael: Digital Revolution - Engaging Audiences. A Cine-Regio report in collaboration with Filmby Aarhus, MCG Film \& Media, 2011.

4 European Audiovisual Observatory: 3D drives European box office to record high in 2010 as market share for European film drops, Press Release, Strasbourg, 9 May 2011, http://www.obs.coe.int/about/oea/pr/ mif2011_cinema.html (2012. 03. 12., a kézirat leadásakor már nem elérhetö).

5 EPERJESI János: Filmipar Európában. Európai filmtámogatási rendszerek - 3. rész. http://www.filmtett.ro/ cikk/2643/filmipar-europaban-europai-filmtamogatasi-rendszerek-3-resz (2015. 10. 06.).

6 Vannak olyan szerzők, akik szerint a filmfinanszírozás megjelenése a totalitárius törekvésekhez köthetö, amelyek a filmet mint a propaganda eszközét támogatták, lásd például: AmıEL, Olivier: Chargé d'enseignement à l'Université de Perpignan: Financement public du cinéma et diversité culturelle, intervention au colloque du 29 septembre 2008, Paradoxes du cinéma français. Fondation Res Publica.

7 Ilyen adóbevételek származhatnak például mozijegyeladásból vagy nemzetilottó-bevételekből.

8 Le Crédit National Archives pour une histoire de la production cinématographique francaise, http://www. cinematheque.fr/sites-documentaires/credit_national/rubrique/historique-de-l-institution-le-service-desprets-et-le-cinema.php (2015. 10. 06.).

9 EperJesI: i. m., 1. 
seket (például az Új Hullám, a „Nouvelle Vague” mozgalmát) támogatta, és csak az 1980-as évek közepétöl, a tömegfogyasztás kibontakozásának hatására fordult az ún. művészfilmek felé. ${ }^{10}$

Az európaitól eltérő utat járt be az Egyesült Államok filmtámogatási politikája. Az ösztönző erőt egy új filmtámogatási modell megjelenéséhez az 1960-as évek recessziója jelentette. 1963-ban 50 éves mélyponton volt az amerikai filmek száma (mindössze 121 nagyjátékfilmet mutattak be), majd 1964-ben minden idők legnagyobb arányát érték el a külföldi filmek (361 külföldi filmbemutató állt szemben 141 amerikai filmmel). ${ }^{11}$ A pénzügyi nehézségek fokozódásával és a stúdiókapacitások csökkenésével egyre több amerikai filmet készítettek más országokban, elsősorban Angliában. Ezt a jelenséget nevezik szökevény produkciónak (runaway productions), utalva az először az Egyesült Államokban bemutatni kívánt, de egy másik ország területén forgatott filmekre. Olyan jelenség ez, amely azóta is meghatározó mozgatórugója az amerikai filmtámogatási politikának.

Ennek a folyamatnak a visszafordítására, azaz a hollywoodi filmipar megerősítésére vezették be az adókedvezmények rendszerét mint a filmfinanszírozás új technikáját az Egyesült Államokban. ${ }^{12}$ Szemben az ún. közvetlen támogatásokkal, amelyeket az egyes államok a központi költségvetés által is finanszírozott szervezeteken keresztül, pályázatok útján juttatnak el a filmipari szereplők, területek és tevékenységek részére, ezeknek az ún. közvetett támogatásoknak az alapvető célja, hogy az állam külső forrásokat vonjon be az ágazatba, lehetöleg úgy, hogy az adókedvezményekből eredő adókiesést a bevont tőke felhasználásából eredő adóés járulékbefizetésekkel ellensúlyozza. A vállalkozások szempontjából ezeknek a kedvezményeknek a lényege, hogy a befektető a létrejött filmprodukció sikerétől függetlenül, a befektetett pénzeszköz okán és a film költségvetéséhez igazodva jut adókedvezményhez, azaz kockázatmentes befektetési lehetőséget kínálnak. Az adókedvezmény általános fogalom, a valóságban többféle formát ölthet: többnyire adólevonás (adóalap-csökkentés) és/vagy adójóváírás (a fizetendő adó csökkentése) formájában jelenik meg.

Az 1971-ben, a hazai filmelőállítási törvénnyel (Domestic Film Production Act) bevezetett kedvezményrendszert az Egyesült Államokban egészen az 1980-as évek közepéig fenntartották, ennek hatására Hollywood és a kaliforniai filmgyártás újra megerősödött. Ezt követően az újabb változást az Egyesült Államok számára az 1990-es évek második felétől a szomszédos Kanada számos államában megjelent adójóváírási rendszerek jelentették, amelyek a kedvező árfolyam és a közel $70 \%-k a l$ alacsonyabb munkabérköltségek mellett versenyképesnek bizonyultak, megindítva a „szökevény produkciók” újabb jelentős hullámát, ismét elhódítva a nagy költségvetésű amerikai filmprodukciók jelentős részét az Egyesült Államokból. Ennek hatására jött létre az Egyesült Államokban a filmgyártás terén nyújtott adókedvezmé-

10 Gimello-Mesplomb, Frédéric: Le prix de la qualité. L'Etat et le cinéma français (1960-1965), Politix, 2003/61, 95-122.

11 DiRks, Tim: The History of Film, The 1960s, The End of the Hollywood Studio System, The Era of Independent, Underground Cinema, Part 1. http://www.filmsite.org/60sintro.html (2015. 10. 06.).

12 BAKKER: i. m. 
nyek és más pénzügyi támogatások második generációja. Tekintettel az időközben bekövetkezett változásokra, a tömegfogyasztásra és a filmterjesztés globális alternatíváinak megsokszorozódására, ezek a kedvezmények egy világméretü verseny kiindulópontjává váltak.

Az adókedvezményben rejlö versenyelőny lehetőségét látva, az Egyesült Államok egyes államai fokozatosan egymással versengő rendszereket alakítottak ki a filmprodukciók elhódítása érdekében. 2002-ben még csak öt államban volt érvényben filmgyártáshoz kapcsolódó kedvezmény, 2010-re azonban - a 2004-ben bevezetett szövetségi adókedvezmény mellett - már negyvenöt államban volt ilyen támogatás, ezek közül huszonnyolc állam adójóváírás formájában biztosított előnyt a területén forgatott filmes produkcióknak. ${ }^{13} \mathrm{Az}$ utóbbi évek gazdasági visszaesésének hatására a filmes és szórakoztatóiparnak juttatott állami adókedvezmények rendszerével szembeni kritikus hangok felerösödtek ugyan, jelenleg azonban mindössze tizenegy államban nincs speciális filmtámogatási program érvényben, míg huszonhat állam alkalmazza az adójóváirás rendszerét a helyben forgatott filmprodukciók esetében.

Például szolgálhat a kedvezményekre Louisiana, Florida vagy akár New York állam. Louisiana volt az első amerikai állam, amely filmes adókedvezményt vezetett be, és máig 30\%-os átruházható adójóváirást tesz lehetővé az állam területén felmerült költségekböl, amelyhez további $5 \%$ adójóváirás társulhat a helyi munkaerököltségek után. ${ }^{14}$ Ezen túlmenően az átruházható adójóváírás helyett választható az adó-visszatérítés is, hogy gazdaságilag a filmprodukció a lehető legnagyobb előnyt élvezhesse. ${ }^{15}$ Többek között ezek a nagyvonalú kedvezmények késztették a Hollywoodnak otthont adó államot, Kaliforniát arra, hogy 2010-ben új kedvezményrendszert vezessen be, öt éven belül 242 millió dollárnyi átruházható adójóváírást irányozva elő. A kedvezmény alapját egy $20 \%$-os átruházható adójóváírás képezi az államban felmerült költségek után, amely külön kedvezményekkel kombinálva akár a költségek $30 \%$-áig is emelkedhet, és amelyet bizonyos filmes felszerelések adómentes vásárlásának, illetve lízingelésének lehetősége egészít ki. ${ }^{16}$ New York 2008-ban szintén 30\%-ra emelte fel a helyi költségek után járó átruházható adójóváírást, ${ }^{17}$ amelyet New York City további 5\%-kal egészít ki, illetve - amennyiben legalább $75 \%$-ban az állam területén zajlanak - a filmes utómunkák után is igénybe vehető $10 \%$ adójóváírás. ${ }^{18} \mathrm{~A}$ támogatási program éves költségvetése jelenleg 420 millió dollár. ${ }^{19}$

13 LUtheR, William: Movie Production Incentives: Blockbuster Support for Lackluster Policy. Tax Foundation Special Report, January 2010, No. 173, 1-16.

14 KHARABI, Johan-Kemper, Sally: Top 10: United States of Production. http://www.p3update.com/preproduction/ locations/60-locations/top-10-united-states-of-production (2015. 10. 06.).

15 Wells, Steve-Posey, Clyde: Let's Go to the Movies - State Tax Incentives: Heroes or Villains. Journal of State Taxation, 2011/29, 30; valamint Wells, Steve-Posey, Clyde: Big Sky on the Big Screen Act - State Tax Incentives for the Film Industry. Journal of State Taxation, 2008/2009/27, 29-34.

16 Kharabi-Kemper: i. m., 4.

17 HAYES, Dade: New York to triple film, TV tax credit. Variety, 2008. április 10. http://www.variety.com/article/ VR1117983879?refCatld=13 (2015. 10. 06.).

18 Genz, John: Are You Taking Advantage of the New York State Post Production Tax Credit? http://www. eisneramper.com/new-york-state-film-production-credit-211.aspx (2015. 10. 06.).

19 KHARABI-KemPER: i. m. 
Tekintettel a filmgyártás mobilitására és az ebböl is eredő globális gazdasági versenyre, a filmes nagyprodukciókért folytatott verseny nem korlátozódhatott az amerikai kontinensre. Az elmúlt évtizedek során világszerte növekvő mértékben tudatosodott a filmgyártás foglalkoztatást és állami adójövedelmeket növelő hatása. Mindezek nyomán egyre keményebb küzdelem folyik az országok között ennek a rendkívül mobilis iparágnak adott helyszínre csábításáért, elsősorban adójóváírással és más kedvezményekkel, illetve ezzel párhuzamosan a filmgyártáshoz szükséges technikai infrastruktúra, stúdiók létesítésével, az ezekhez nyújtott kedvezményekkel..$^{20} \mathrm{~A}$ filmek forgatásának, az utómunkálatoknak (például a hang- és vizuális effektek létrehozásának) a helyszínére vonatkozó, világméretủ versenynek ugyanis csak egyik tényezőjét jelentik az ország adottságai: a munkaerő vagy a helyszín bérlésének ára, illetve a filmgyártásban közremüködők szakmai színvonala. Emellett a döntő tényező egyre inkább az adókedvezmények megléte. ${ }^{21} \mathrm{~A}$ végeredmény egy folyamatosan éleződő, világméretü verseny mára már nemcsak az Egyesült Államok, Kanada és az Európai Unió tagállamai között, hanem Ausztrália, ${ }^{22}$ Új-Zéland ${ }^{23}$ és számos ázsiai célpont, mint Tajvan, ${ }^{24}$ Szingapú ${ }^{25}$ és Dél-Korea ${ }^{26}$ részvételével. Utóbbiak az elmúlt évtizedekben kapcsolódtak be e globális versenybe. ${ }^{27}$

20 Freeman, Gregory-Kyser, Jack-Sidhu, Nany-Huang, George-Montoya, Michael: What is the cost of runaway production? Jobs, Wages, Economic Output and State Tax Revenue at Risk when Motion Picture Productions Leave California. Los Angeles County Economic Development Corporation, August 2005, http://www. stop-runaway-production.com/wp-content/uploads/2009/07/California_Film_Commission_Study.pdf (2012. 03. 12., a kézirat leadásakor már nem elérhetö).

21 Oxford Economics: Economic Impact of the UK Film Industry, Supported by the UK Film Council and Pinewood Shepperton plc. July 2007, http://www.ukfilmcouncil.org.uk/media/pdf/5/8/FilmCouncilreport190707. pdf (2012. 03. 12., a kézirat leadásakor már nem elérhetö).

22 Ausztrália többek között $40 \%$-os adójóváírást biztosít az elszámolható ausztráliai forgatási költségek vonatkozásában egész estés filmek készítése esetében (produceer offset). https://www.screenaustralia.gov.au/ (2015. 10. 06.).

${ }^{23}$ Az Új-Zéland Filmtámogatási ösztöndij akár $40 \%$-os pénztámogatást biztosíthat a helyi produkciós költségekre, amennyiben koprodukcióról van szó, vagy tartalmilag Új-Zéland jelentősége kiemelkedő. http://www. nzfilm.co.nz/international-productions/incentives (2015. 10. 06.).

24 A gyártási költségekre vonatkozó támogatások kiterjednek például a helyben alkalmazott stáb költségének $30 \%$-ára; a produkciót megelőző tervezés költségeinek $25 \%$-ára (tervezés, R\&D, pénzgyüjtés, elölegezett jegyértékesítés stb.), utómunkálatokra (hangfelvétel, vágás, speciális effektek, hangeffektek, fénybeállitási munkálatok stb.) és komputeres animációkra; a tajvani gyártási periódus alatt előforduló felelősségbiztosítások költségének15\%-ára. http://www.taipeifilmcommission.org/en/Grant/Static/6717 (2015. 10. 06.).

25 A gyártás során elöforduló meghatározott szingapúri költségek akár $40 \%$-áig is terjedhet a támogatás. http:// www.mda.gov.sg/IndustryDevelopment/GrantAndSchemes/Pages/overview.aspx (2015. 10. 06.).

26 Áfa-visszatéritési jogosultság a helyi költségekre, valamint $25 \%$ mértékü pénzösztöndij is elérhető a helyi adóilletékességgel bíró produkciós társaság részére, minimum 10 forgatási nap eltöltése szükséges Koreában, és többek között legalább 900000 USD elköltése a támogatás további feltétele. http://www.kftv.com/ country/Korea_Republic_South/guide/incentives (2015. 10.06.).

272015 augusztusában Thaiföld is bejelentette, hogy programot készít azzal a céllal, hogy a filmforgatások helyszínéül az országot válasszák. A tervekben 15\%-os pénzvisszatérítés szerepel minden az országban elköltött 30 millió baht (860 000 USD) után. http://variety.com/2015/film/asia/thailand-ready-to-establishlocation-filming-incentives-1201568345/ (2015. 10. 06.). 


\section{A versengő kedvezmények amerikai kritikája}

Miközben a filmes adókedvezmények száma nemzetközi szinten folyamatosan nő, az utóbbi években - föleg az Egyesült Államokban - e kedvezmények gazdasági hatékonyságát megkérdőjelező tanulmányok is megjelentek. ${ }^{28}$ Ezeknek a támogatási intézkedéseknek és az államok közötti fokozódó versengésnek egyik leghatározottabb, legkövetkezetesebb kritikusa a washingtoni székhelyü Tax Foundation, amelynek számításai szerint az államok az elmúlt évtizedben majdnem 6 milliárd dollárt költöttek adókedvezményekre. Álláspontjuk szerint azonban ezek a kedvezmények nem váltották be a hozzájuk füzött reményeket: a filmgyártás által teremtett munkalehetőségek többnyire átmeneti jellegüek, és a kieső állami jövedelem nem térül meg. ${ }^{29}$ Azt természetesen elismerik, hogy az adókedvezmények ösztönzik a filmes tevékenységet. Felhívják azonban a figyelmet arra, hogy a legtöbb támogatási program esetén rejtve marad, valójában mennyibe kerülnek a kedvezmények az adófizetők számára, és mennyi tiszta nyereséget hoznak. Véleményük szerint azok a tanulmányok, amelyek az adókedvezmények filmgyártást, foglalkoztatást és befektetést ösztönző hatását hangsúlyozzák, nincsenek figyelemmel arra a tevékenységre, amelyre adókedvezmény nélkül is sor került volna, és nem értékelik a lehetőségköltséget („opportunity cost”), azokat az alternatívákat, amelyek finanszírozásáról az állam lemondani kényszerül. ${ }^{30}$

Michigan állam szenátusának a helyi adójóváirásról készült 2010-es pénzügyi jelentése hasonló következtetésre jutott. „Az adójóváirás természetéből és az általa eredményezett tevékenység jellegéböl következik, hogy a jelenlegi (és bármely reális) adókulcs mellett az állam soha nem lesz képes arra, hogy az adójóváírást »önellátóvá» tegye az állami jövedelem szempontjából; akkor sem, ha az adójóváirás következtében sor kerül olyan vállalati tevékenységekre, amelyek enélkül elmaradtak volna." ${ }^{31}$ Ugyanezeket a kételyeket fogalmazta meg 2004-ben Greg Albrecht, Louisiana állam törvényhozása pénzügyi hivatalának vezető közgazdásza: „Még akkor is, ha a megadott gyártási költségvetéseket 100\%-ban louisianai áruk és szolgáltatók beszerzésére fordították, az ebböl eredő gazdasági elöny nem elegendő ahhoz, hogy olyan mértékü adóbevételt eredményezzen, amely megközelítené azt a szintet, amely az adójóváirás által okozott költségek kiegyenlítéséhez szükséges." ${ }^{32}$ 2009-ben a Wisconsin állami Kereskedelmi Hivatal egy ugyancsak éles

28 Schonauer, R. Joshua: Star Billing? Recasting State Tax Incentives for the „Hollywood” Machine. Ohio State Law Journal, 2010/2.

29 Henchman, Joseph: Poor Reviews Prompt States to Cry Cut! on Film Tax Incentives. http://news.heartland. org/newspaper-article/2011/06/18/poor-reviews-prompt-states-cry-\%E2\%80\%98cut\%E2\%80\%99-film-taxincentives (2012. 03. 12., a kézirat lezárásakor már nem elérhetö).

30 Совв, Kathy: Roll the credits... and the tax incentives - Cities, states and even countries spar for film production business, but at what cost? http://www.minneapolisfed.org/publications_papers/pub_display. cfm?id=1309 (2012. 03. 12., a kézirat lezárásakor már nem elérhetö).

${ }^{31}$ ZIN, David: Film Incentives in Michigan, Issue Paper of the Michigan Senate Fiscal Agency. http://www.senate.michigan.gov/sfa/Publications/Issues/FilmIncentives/FilmIncentives.pdf (2015. 10. 06.).

32 AlbRECHT, Greg, chief economist for Louisiana's Legislative Fiscal Office, In: Nothdurft, John: Film Tax Credits: Do They Work? The Heartland Institute, Policy Documents http://heartland.org/policy-documents/ film-tax-credits-do-they-work (2012. 03.12., a kézirat lezárásakor már nem elérhetö). 
tanulmányban az adó-visszatérítés eszközét a gazdaságilag egyik legkevésbé hatékony eszközként jellemezte. ${ }^{33}$ Igaz ugyan, hogy e hatástanulmányok egyike sem tér ki olyan pozitív szemléletbeli változások mérésére, mint amilyen a helyi közösség imázsépítése a filmgyártáson keresztül, vagy annak a hozadéknak a számszerüsítésére, amelyet az alacsony képzettségú munkásnak a biztonságérzete jelenthet, amelyet - ha csak egy időre is - szintén egy-egy filmprodukció biztosít a munkanélküliséggel szemben.

Az adókedvezmények kritikája szerint nem állja meg a helyét a gazdaságra gyakorolt, átfogó ösztönző hatás sem: „Ha be is válnak a filmes adókedvezmények és megnövelik a helyi filmgyártást, az ebből eredő általános gazdasági ösztönző hatás meglehetősen alacsony marad" - vélik egyes elemzők. ${ }^{34} \mathrm{~A}$ hosszú távú foglalkoztatás növelését nem lehet az átlagosan 18 hónaposra nyúló produkciós időszakokra alapozni, tekintettel arra, hogy az államok egymással állnak versenyben, annak a valószínüsége pedig, hogy a filmes produkciók egymást folyamatosan követik, nagyon kicsi. A turizmus fellendítését hangsúlyozó érvelés is félrevezető lehet, hiszen a cselekmény és a filmforgatás helyszíne nem feltétlenül esik egybe. ${ }^{35}$

A jelenlegi, versenyző adókedvezményekre épülő rendszert pedig egyenesen károsnak tartja a Tax Foundation: „Az egyetlen, amit ezek az intézkedések eredményeznek, az a további adókedvezmények és támogatások bevezetésének igénye." ${ }^{36} \mathrm{Ez}$ lefelé nivelláláshoz („,race to the bottom”) vezet, a tagállamok által bevezetett versengő kedvezményeknek az egyedüli nyertese a filmipar, minden más résztvevő veszít.

A Tax Foundation az amerikai államok közötti versengésnek három megoldási lehetőségét vázolja fel. ${ }^{37}$ Lehetségesnek tartja egyfelöl, hogy egyes államok egyoldalúan felhagynak a versengéssel: úgy döntenek, hogy nem éri meg folytatni a versenyt más államok (mint Louisiana és Michigan) bőkezü kedvezményeivel. Az olyan államok, amelyek nem rendelkeznek egyéb vonzerővel a filmgyártás számára, ezáltal minden bizonnyal elveszítik a filmprodukciókat. Ezzel egyidejüleg azonban jövedelmek szabadulnak fel, amelyeket más, hosszabb távú célok érdekében használhatnak fel.

Valóban, 2010-2011-ben több amerikai állam is (Arizona, Arkansas, Idaho, lowa, Kansas, Maine, New Jersey, Washington) a kedvezmények megszüntetése vagy felfüggesztése mellett döntött, és más államokban (Alaszka, Connecticut, Georgia, Hawaii, Michigan, Missouri, Új-Mexikó, Rhode Island, Wisconsin) is történtek kezdeményezések a támogatások csökkentésére vagy megszüntetésére. Vannak azonban olyan államok is, amelyek a kedvezmények fenntartása, illetve fokozása mellett döntöttek (Kalifornia, Utah, Virginia például további kedvezményeket vezettek be). ${ }^{38}$

33 Malyshev, Alexander: Financing Film through Aggressive Tax Incentives - A Losing Proposition for the States. Media Law and Policy, 2010/19, 234.

34 New England Public Policy Center at the Federal Reserve Bank of Boston, In: Nothdurft: i. m.

35 "Clearly for example Pennsylvania would get no tourist boost even if it was the filming location of a movie that was set in Maryland ('Annapolis')." MaLYSheV: i. m., 235-236.

36 Cineuropa Industry Report: Financing - Study: Film Tax Credits, Production Incentives Fail to Spur Economic Growth. http://cineuropa.org/2011/dd.aspx?t=dossier\&l=en\&tid=1365\&did=134997 (2015. 10. 06.).

37 LUTHER: i. m.

38 Henchman: i. m. 
Újabban az államok a filmgyártó vállalat kötelezettségévé teszik a könyvvizsgálati beszámoló benyújtását, mielőtt az adókedvezmény bármely formája érvényesíthető lenne. ${ }^{39}$ Összességében 2014-ben 39 állam és Puerto Rico alkalmaztak filmgyártásra ösztönző adókedvezményeket.

A második megoldási lehetőséget a Tax Foundation szerint az jelentené, ha valamennyi állam közös megegyezéssel megszüntetné a filmiparra vonatkozó adókedvezményeket. Ennek az önkéntes megállapodáson alapuló megoldásnak a gyakorlati korlátja, hogy a megállapodást megszegő állam nagy nyereségre tehetne szert a többiek rovására. Ez pedig ismét csak az államok közötti versengéshez vezethetne.

A harmadik alternatívát a föderális megoldás jelenthetné. Egyes szerzők azt javasolták, hogy a Kongresszus a Kereskedelmi cikkely (Commerce Clause ${ }^{40}$ segítségével vessen véget „az államok közötti gazdasági háborúnak”, és akadályozza meg, hogy az államok „pénzügyi kedvezmények segítségével ösztönözzenek vállalatokat arra, hogy az adott államban telepedjenek le, ott maradjanak vagy ott bővítsék vállalkozásukat". ${ }^{41}$ Azt azonban maga a Tax Foundation is elismeri, hogy a Kereskedelmi cikkelyben foglalt hatáskörök ilyen célú használata új precedenst teremtene, ami egyéb, a filmiparon túlmenő problémák forrása lehetne.

Az elöbbiekben ismertetett álláspontok jól tükrözik azokat a hangokat, amelyek a filmes adókedvezmények között kialakult verseny káros hatásaira hívják fel a figyelmet. A Tax Foundation által megfogalmazott kritika mélyebb megértéséhez ugyanakkor érdemes megjegyezni azt, hogy a szervezet nemcsak a filmes adókedvezményeket tartja károsnak, hanem általában véve az ágazati adókedvezményeket. Véleményük szerint, míg az adórendszerek közötti általános verseny kedvező lehet mind a fogyasztók, mind a gazdasági növekedés szempontjából, az ágazati adókedvezmények csak „...átcsoportositják a jövedelmet a többségtöl a kisebbséghez”. ${ }^{42}$ További érdekesség, hogy bár a szervezet hangsúlyozza a beható elemzés hiányát és számos szempontot közgazdasági igényességgel tárgyal, elemzése során figyelmen kívül hagyja a filmgyártásért folytatott globális verseny kontextusát. Nem vizsgálja, milyen következményekkel járna a kedvezmények egységes megszüntetése az Egyesült Államokban, tekintettel az európai és más nemzetközi vetélytársakra.

$A z$ adókedvezmények rendszerének globális jellege ugyanakkor hangsúlyosan jelent meg abban a vitában, amely az Európai Bizottság Filmművészeti Közleményének ${ }^{43}$ átgondolást igénylö területeiről szóló vitaanyaga kapcsán bontakozott ki a Bizottság, az érintett tagállamok és piaci szereplők körében az Európai Unióban.

39 National Conference of State Legislatures, 28 March, 2014. http://www.ncsl.org/research/fiscal-policy/ state-film-production-incentives-and-programs.aspx (2016. 01. 18.).

40 A Kereskedelmi cikkely az Egyesült Államok Alkotmányának I. Cikk 8. § egyik pontjára utal, amely a Kongresszus hatáskörét írja le adók, vámok, illetékek és járulékok kivetésére... többek között az egyes tagállamok közötti... kereskedelem szabályozására. http://hungarian.hungary.usembassy.gov/constitution_in_ hungarian.html (2016. 01. 18.).

41 Burstein, Melvin and Rolnick, Arthur of the Federal Reserve Bank of Minneapolis. In: Henchman: i. m.

42 LUTHER: i. m.

43 Communication from the Commission to the Council, the European Parliament, the Economic and Social Committee and the Committee of Regions on certain legal aspects relating to cinematographic and other audiovisual works, Brussels, 26.09.2001, COM(2001)534 final, HL C 43, 16/02/2002, 6-17. 


\section{Az Európai Unió állami támogatási szabályai a filmgyártás területén és a 2001-es Filmművészeti Közlemény}

Az Európai Unió Müködéséről Szóló Szerződés 107. cikkének (1) bekezdése fő szabályként tiltja az állami támogatások bevezetését, azaz bármely olyan állami forrásból nyújtott pénzügyi előnyt, „...amely bizonyos vállalkozásoknak vagy bizonyos áruk termelésének elönyben részesítése által torzítja a versenyt, vagy azzal fenyeget, amennyiben ez érinti a tagállamok közötti kereskedelmet”.

A következő két bekezdés, amelyek a megengedett, ${ }^{44}$ illetve az Európai Bizottság által engedélyezhetö ${ }^{45}$ támogatásokat jelölik meg, ugyanakkor egyértelművé teszi, hogy a valóságban inkább a verseny vagy az egységes belső piac szempontjából káros és a megengedett támogatások közötti különbségtételről van szó.

Tekintettel a filmipar kulturális jelentőségére és a filmtámogatások eredendően kulturális célkitüzéseire, a filmgyártás támogatása az Európai Bizottság gyakorlatának megfelelően a 107. cikk (3) d) pontja, az 1992-es Maastrichti Szerződés által bevezetett ún. kulturális kivétel alapján kerül megítélésre, mint „...a kultúrát és a kulturális örökség megörzését elömozdító támogatás”, amely engedélyezhető, „ha... az az Unión belüli kereskedelmi és versenyfeltételeket nem befolyásolja a közös érdekkel ellentétes mértékben".

Azokat a feltételeket, amelyeket a támogatási intézkedésnek ennek érdekében teljesítenie kell, a Filmmüvészeti és más audiovizuális müvek egyes jogi vonatkozásairól szóló, 2001-ben kiadott bizottsági közlemény ${ }^{46}$ ismerteti, amelyet az Európai Bizottság több ízben, legutóbb 2012. december 31-ig meghosszabbított. ${ }^{47}$

A Filmmüvészeti Közlemény - az általános jogszerüség, ${ }^{48}$ azaz az egyéb szerződéses rendelkezések tiszteletben tartásának alapkövetelményén kívül - az alábbi legfontosabb követelményeket határozta meg:49

- Kulturális célkitüzés: ${ }^{50}$ a támogatást „kulturális termékhez” kell nyújtani, azaz a tagállamoknak biztosítaniuk kell, hogy a támogatott termék (a szubszidiaritás elvének alkalmazásával összhangban) ellenőrizhető tagállami kritériumok szerinti kulturális tartalommal rendelkezzék.

- Korlátozott területiség (territorializáció): 51 a gyártónak lehetővé kell tenni, hogy a film költségvetésének legalább $20 \%$-át más tagállamokban költhesse el. Ezáltal előírható a kedvezményezett számára, hogy a támogatásban részesülő

44 EUMSZ 107. cikk (2) bekezdés.

45 EUMSZ 107. cikk (3) bekezdés.

46 Communication from the Commission to the Council, the European Parliament, the Economic and Social Committee and the Committee of Regions on certain legal aspects relating to cinematographic and other audiovisual works, Brussels, 26.09.2001, COM(2001)534 final, HL C 43, 16/02/2002, 6-17.

47 A Bizottság közleménye a filmművészeti és más audiovizuális alkotásokkal kapcsolatos bizonyos jogi szempontokról szóló, 2001. szeptember 26-i bizottsági közlemény (Filmművészeti Közlemény) állami támogatásokra vonatkozó értékelési szempontjairól, HL C 31/1, 2009.2.7. [a továbbiakban: Filmművészeti Közlemény (2001)].

48 Filmművészeti Közlemény (2001), 2.3. bekezdés a) pont.

49 Filmművészeti Közlemény (2001), 2.3. bekezdés b) pont.

50 Filmművészeti Közlemény (2001), 2.3. bekezdés b) pont (1).

51 Filmművészeti Közlemény (2001), 2.3. bekezdés b) pont (2). 
film vagy tv-müsor gyártási költségvetésének minimum $80 \%$-át a támogatást nyújtó tagállamban költse el.

- Kiegészítő jelleg: ${ }^{52}$ alapszabály szerint az állam által nyújtott támogatás nem haladhatja meg a költségvetés 50\%-át, kivételt képeznek ez alól a nehezen megvalósítható és az alacsony költségvetésű filmek.

- Speciális kiegészítő támogatások tilalma: ${ }^{53}$ különálló filmgyártási tevékenységre, például utómunkálatokra támogatás nem nyújtható, ezáltal határozott munkafolyamatokat az adott tagállamba csábítani nem lehet. ${ }^{54}$

Ezt a követelményrendszert eredendően az Európában hagyománynak számító, nemzeti, kulturális filmipart támogató intézkedések alapján határozta meg az Európai Bizottság, mintájaként pedig a francia filmtámogatási rendszer felülvizsgálata szolgált. Az évezredforduló után előtérbe kerülő, a nagyprodukcióknak az adott ország területére vonzását célzó, az abban rejlő gazdasági potenciál kiaknázására irányuló állami támogatásokat azonban elsődlegesen inkább gazdasági, mint kulturális érdekek motiválták. Ennek következtében a Bizottság közelebbről vizsgálta döntéseiben, hogy teljesítik-e a javasolt intézkedések a kulturális kivétel feltételeit. ${ }^{55}$

Ez mindenekelőtt a kulturális célkitüzés behatóbb vizsgálatában öltött testet. A nemzeti, kulturális motivációjú filmtámogatások során a kulturális célkitűzés többnyire magától értetődően adott volt. A nagyprodukciókra irányuló kedvezmények vizsgálata során ugyanakkor a kulturális követelménynek való megfelelés sarkalatos kérdéssé vált, szükségessé téve a támogatott filmek kulturális tartalmát biztosító tagállami kritériumok részletesebb elemzését. Ez azonban - tekintettel a kultúra nehezen megragadható fogalmára, valamint az Európai Unió és a tagállamok közötti hatáskörmegosztásra - korántsem egyszerủ és ellentmondásoktól mentes.

Bár a Maastrichti Szerződés külön fejezetet szentelt a kultúrának, a kultúra fogalmát nem definiálta, ${ }^{56}$ valamint jelezte, hogy a kultúra elsődlegesen nemzeti hatáskörbe tartozik. Ennek megfelelően a tagállamok jogosultak a filmtámogatás kulturális célkitűzésének, a támogatandó filmek kulturális tartalmának meghatározására, az Európai Bizottság e tekintetben csak akkor léphet fel, ha a tagállamok nyilvánvaló hibát („,manifest error”) követnek el. A Bizottság jogköre és kötelezettsége döntően arra korlátozódik, hogy ellenőrizze, vajon a kulturális tartalom meghatározása ellenörizhető tagállami szintü követelmények alapján történik-e. ${ }^{57}$

52 Filmmüvészeti Közlemény (2001), 2.3. bekezdés b) pont (3).

53 Filmmüvészeti Közlemény (2001), 2.3. bekezdés b) pont (4).

54 Tosıcs Nóra: Audiovizuális politika. In: Kende Tamás-Szűcs Tamás (szerk.): Bevezetés az Európai Unió politikáiba. Complex, Budapest, 2011.

55 Broche, Jérôme-ChatterJee, Obhi-Orssich, Irina-Tosics, Nóra: State aid for films: a policy in motion? Competition Policy Newsletter, 2007/1, 44-48.

56 CAstendyk, Oliver-Dommering, Egbert J.-Scheuer, Alexander: European Media Law. Kluwer Law International, The Netherlands, 2008.

57 Erről lásd bővebben KIRÁlY Miklós: Unity and diversity: the cultural effects of the law of the European Union. ELTE Eötvös Kiadó, Budapest, 2011. 


\section{Versengő kedvezmények Európában - mit mondtak a piaci szereplök?}

\subsection{A Filmmüvészeti Közlemény felülvizsgálata, a Bizottság 2011-es vitaanyaga}

A 2001-es Filmművészeti Közleményben kiadott értékelési szempontokat a Bizottság eredetileg három évre rögzítette, így már 2003-ban történtek kezdeményezések annak felülvizsgálatára, ${ }^{58}$ ám a közleményt végül változatlan formában hoszszabbították meg 2012 végéig. ${ }^{59}$ A 2009-es meghosszabbítással egyidejüleg azonban a Bizottság felhívta a figyelmet azokra az új filmtámogatási tendenciákra, amelyek szükségessé tehetik a szempontrendszer felülvizsgálatát. llyen jelenségként azonosította a filmgyártástól eltérő tevékenységhez nyújtott támogatások kérdését (például: filmterjesztés és digitális vetítés), illetve a regionális filmszakmai támogatási programok számának növekedésén túl a támogatási versenyt is, azazhogy „[e] gyes tagállamok között verseny alakult ki annak érdekében, hogy állami támogatások felhasználásával vonzzák a föként egyesült államokbeli filmgyártó nagyvállalatok belföldi beruházásait". ${ }^{60}$

A fentiek fényében tehát a Bizottság 2011-ben vitaanyagot tett közzé, ${ }^{61}$ és nyilvános konzultációt kezdeményezett a Filmmüvészeti Közlemény szempontrendszerének felülvizsgálatáról. A vitaanyagban többek között átgondolást igénylő területként szerepelt a tagállamok közötti támogatási verseny is. Ezen túlmenően olyan átfogó kérdéseket vetettek fel, mint a filmgyártáson kívüli filmes tevékenységek támogatása, a maximális támogatási intenzitások kérdése, a területi feltételek (ún. territorializációs szabályok) létjogosultsága, illetve a digitális forradalom (elsősorban a digitális gyártási és terjesztési technológiák) hatása.

„Hogyan kellene ellenőrizni a jelentős filmprodukciók adott helyszínre vonzásáért indított "támogatási versenyt «?" - e címszó alatt foglalta össze a vitaanyag azt a globális trendet, amely a filmtámogatási kedvezmények növekedésének hátterében áll. ${ }^{62}$ „Ha egy ország megfelelö, nagy filmstúdióval rendelkezik, arra fog törekedni, hogy odavonzza ezeket a produkciókat, és a lehetö legnagyobb haszonra tegyen szert azáltal, hogy a produkció helyi filmszolgáltató vállalkozásokat, szereplöket, stábot foglalkoztat, illetve létesítményeket és kisegítő szolgáltatások széles körét veszi igénybe. A kasszasikereket jellemzően adóösztönzőkkel és olyan intézkedé-

58 2003-ban a Bizottság vitaanyagot tett közzé, elsősorban a területhez kötöttség szabályozásának felülvizsgálatát célozva. Ebben a témakörben 2008-ban a Bizottság felkérésére tanulmány készült: „A filmtámogatási rendszerekben szereplő territorializációs követelmények gazdasági és kulturális hatásáról, különös tekintettel a koprodukciókra", http://ec.europa.eu/avpolicy/docs/library/studies/territ/final_rep.pdf (2015. 10. 16.).

59 A Bizottság közleménye a filmművészeti és más audiovizuális alkotásokkal kapcsolatos bizonyos jogi szempontokról szóló, 2001. szeptember 26-i bizottsági közlemény (filmművészeti közlemény) állami támogatásokra vonatkozó értékelési szempontjairól, HL C 31/1, 07/02/2009, 1.

60 A Bizottság közleménye a filmművészeti és más audiovizuális alkotásokkal kapcsolatos bizonyos jogi szempontokról szóló, 2001. szeptember 26-i bizottsági közlemény (Filmművészeti Közlemény) állami támogatásokra vonatkozó értékelési szempontjairól, HL C 31/1, 07/02/2009, 1.

61 Európai Bizottság: Vitaanyag - A filmekhez és egyéb audiovizuális alkotásokhoz nyújtott állami támogatás értékelése [a továbbiakban: Európai Bizottság: Vitaanyag (2011)]. http://ec.europa.eu/competition/ consultations/2011_state_aid_films/issues_paper_hu.pdf (2015. 10. 06.).

62 Európai Bizottság: Vitaanyag (2011), (29)-(37) bekezdés. 
sekkel vonzzák az országba, amelyek meghatározott területeken elösegítik az ilyen nemzetközi játékfilmek és tv-müsorok gyártását." ${ }^{\prime 3} \mathrm{~A}$ vitaanyag rámutatott az amerikai és az európai filmek átlagos költségvetése közötti lényeges eltérésre (a jelentős, amerikai finanszírozású filmek gyártási költségvetése átlagosan 65 millió dollár körüli, a legdrágább filmeké több mint 200 millió USD). ${ }^{64}$ Aggályokat fogalmazott meg azzal kapcsolatban, hogy „...miközben a támogatások biztosithatják, hogy ezeket a nagy költségvetésü filmeket inkább Európában, és nem máshol gyártják, az ilyen támogatások torzítják az európai filmgyártási helyszínek közötti versenyt”. ${ }^{65}$ Felhívta a figyelmet arra is, hogy a Filmmüvészeti Közlemény által engedélyezett $50 \%$-os általános támogatási intenzitás igen nagy támogatási összegeket tesz lehetővé az ilyen produkciók esetében. Noha elismerte, hogy ezen a módon közvetve támogathatók az európai filmszolgáltatások, aminek egyéb, járulékos előnyei is lehetnek, összességében azonban negatívan ítélte meg a kialakult helyzetet. Úgy vélte, hogy „...mind az ágazatot, mind az európai adófizetöket hátrányosan érinti, hogy az állami támogatások ilyen felhasználása a tagállamok közötti támogatási verseny kialakulását eredményezi”. ${ }^{66}$ Hangsúlyozta, hogy „....a támogatási versenyek elkerülése pontosan egyike a Szerződésben rögzített állami támogatási rendelkezések céljainak". ${ }^{67}$

A nagyprodukciók támogatásával kapcsolatban két konkrét problémakört vázolt fel. Egyrészt úgy vélte, hogy az ilyen produkciókhoz kapcsolódó profitok nagyrészt az EU-n kívül maradnak, és emiatt nem feltétlenül járulnak hozzá az ágazat hoszszú távú fenntarthatóságához. ${ }^{68}$ Másrészt kiemelte, hogy a jelentős amerikai nagyprodukciók számára - európai versenytársaikkal ellentétben - nem okoz gondot a magánfinanszírozáshoz való hozzájutás („, a kérdés nem az, hogy sor kerül-e a film gyártására, hanem hogy a film gyártására hol fog sor kerülni”), ezért a vitaanyag szerint az ilyen támogatás szükségessége nem nyilvánvaló.

A vitaanyag egyértelmúvé tette azt is, hogy a Filmművészeti Közlemény szempontrendszerének kidolgozásakor még nem voltak, nem lehettek tekintettel a jelenlegi támogatási versenyre. A támogatási verseny ellenőrzése, az eredeti célkitűzések megóvása érdekében nagyobb hangsúly helyeződött arra a kritériumra, amely szerint a filmnek „kulturális terméknek” kell lennie. ${ }^{69} \mathrm{~A}$ Bizottság tapasztalatai szerint azonban a kulturális követelmények szisztematikus vizsgálata a gyakorlatban problematikusnak bizonyult. Véleménye szerint a jelenlegi kritériumok nem megfelelőek ahhoz, hogy elejét vegyék a versengő kedvezményeknek Európában. ${ }^{70}$

A Bizottság ugyanakkor elismerte azt is, hogy nehéz meghatározni azokat a standard szabályokat, amelyekkel kizárható, vagy legalábbis korlátozható a jelentős kül-

63 Európai Bizottság: Vitaanyag (2011), (31) bekezdés.

64 The Numbers - Glossary of Movie Business Terms. http://www.the-numbers.com/glossary.php (2015. 10. 16.).

65 Európai Bizottság: Vitaanyag (2011), (32) bekezdés.

66 Európai Bizottság: Vitaanyag (2011), (33) bekezdés.

67 Európai Bizottság: Vitaanyag (2011), (33) bekezdés.

68 Európai Bizottság: Vitaanyag (2011), (34) bekezdés.

69 Európai Bizottság: Vitaanyag (2011), (35) bekezdés.

70 Európai Bizottság: Vitaanyag (2011), (36) bekezdés. 
földi produkcióknak nyújtott támogatás okozta torzulás. ${ }^{71}$ A vitaanyag két lehetséges megoldást vázolt fel: egyrészt felvetette annak lehetőségét, hogy az egy filmre adható támogatás maximális összegét elöre meghatározzák a Filmmüvészeti Közlemény részeként. ${ }^{72}$ Emellett lehetségesnek tartotta, hogy valamennyi, vagy a meghatározott összeghatár feletti támogatás nyújtását ahhoz a feltételhez kössék, hogy a filmgyártó a támogatás összegét újból befektesse vagy visszafizesse, amennyiben a produkció nyereséges. ${ }^{73}$

\subsection{A nyilvános konzultáció eredménye}

A megadott határidőre összesen 98 vélemény érkezett, melyeket a Bizottság honlapján közzétett. ${ }^{74} A$ hozzászólók jelentős része - elsősorban természetesen a nagyprodukciókra irányuló kedvezményeket fenntartó tagállamok többsége (így Belgium, az Egyesült Királyság, Franciaország, Írország, Németország) $)^{75}$ és a piaci szereplők - vitatták a támogatási versennyel kapcsolatban a vitaanyagban megfogalmazott aggályokat, és a filmipar, illetve a filmes támogatások globális meghatározottságát hangsúlyozták.

A tagállami hatóságok hozzászólásainak többsége felhívta a figyelmet a fokozódó globális versenyre (az USA tagállamai, Kanada, Ausztrália, Új-Zéland, valamint Ázsia), és kiemelték, hogy a jelenlegi tagállami támogatási rendszerek leépítése az egész európai filmipart veszélybe sodorná. Az Egyesült Királyság magának a támogatási versenynek a meglétét is megkérdőjelezte. Az Egyesült Királyság kormánya, annak hivatalai és közintézményei által küldött vélemények hiányolták a bizottsági vitaanyagból a támogatási versenyre egyértelműen utaló bizonyítékokat, valamint annak kimutatását, hogy ez a belső piacra negatív hatást gyakorolna, potenciális vagy valós veszélyt jelentene. ${ }^{76}$ Ebbe az irányba mutatott Franciaország válasza

71 Európai Bizottság: Vitaanyag (2011), (37) bekezdés.

72 „Egy lehetséges megoldást az jelentene, ha a támogatás maximális értéke produkcióként egy meghatározott összegre korlátozódna, azt feltételezve, hogy a nagyon nagy költségvetésű filmek a szükséges előzetes finanszírozáshoz üzleti csatornákon keresztül is hozzájuthatnak."

73 Európai Bizottság: Vitaanyag (2011), (37) bekezdés.

$74 \mathrm{http} / / /$ ec.europa.eu/competition/consultations/2011_state_aid_films/index_en.html\#contributions (2015. 10. 16.). Jelen elemzés során azokat a véleményeket vettük figyelembe, amelyek angol, német, francia, olasz, spanyol vagy holland nyelven íródtak, így kilenc véleményt nem vizsgálhattunk. A teljesség kedvéért itt megemlítjük azokat a dohányzás káros egészségügyi hatásai ellen küzdő szervezeteket - Heart of Mersey, Imperial College, N Lincs SmokeFree Alliance, Tobacco free Norfolk Alliance, UK Faculty of Public Health -, amelyek véleményt nyújtottak be. Egyöntetüen amellett foglaltak állást, hogy azon filmek, amelyekben megjelenik a dohányzás mint képi elem, támogatásra nem lennének jogosultak.

75 A magyar hatóságok az első körben nem nyújtottak be választ a vitaanyagra.

76 Az American Assembly válaszában ugyanakkor hivatkozik a korábban általunk is idézett Oxford Economics The Economic Impact of the UK Film Industry c. tanulmányára, hangsúlyozva, hogy az Egyesült Királyság által adott adókedvezmények nem titkolt célja éppen az volt, hogy a Harry Potter című filmet jegyző Warner Bros cég csehországi áttelepülési szándékát a kedvezőbb feltételekkel megakadályozza. A tanulmány 8 . oldalán olvasható elemzés azt sugallja, hogy az Egyesült Királyság célja a versenyelőny megszerzése és fenntartása: „so that in 2010 UK film costs are around 40\% lower than those in the US and $7 \%$ lower than those in the Czech Republic, after accounting for the incentives on offer in both countries". 
is, amely e támogatások jelentőségét kívánta relativizálni, kiemelve, hogy a francia rendszerben a nemzetközi adókedvezmény éves szinten mintegy 6 millió eurót tesz ki, ami a 150 millió eurós filmtámogatási költségvetéshez képest csekély, mondhatni elhanyagolható.

Emellett több nemzeti hatóság hangsúlyozta válaszában a helyi filmgyártást ösztönző kedvezmények pozitív oldalát. A támogatások elönyös hatásaként többen is kiemelték a több európai koprodukció elkészültét; a jobb felkészültségü, gyakorlott audiovizuális stáb megerősödését; a technikai, müvészeti know-how elsajátításának lehetőségét; a többnyire egyszerre több tagállamot is érintő gazdasági és kulturális elönyöket.

A tagállami hatóságok hozzászólásainak többsége egyértelműen kiállt a Filmmüvészeti Közlemény eredeti szempontrendszerének fenntartása mellett. A kulturális követelmények kapcsán föként a szubszidiaritás (ez esetben a tagállami kulturális hatáskörök) érvényesítését hangsúlyozták, utaltak továbbá arra, hogy léteznek olyan elfogadott eszközök, amelyek lehetővé teszik annak meghatározását, mi tekinthető európai alkotásnak. Véleményük szerint ilyen a MEDIA program „európai elemek" táblázata, illetve az Európa Tanács európai film koprodukciós egyezménye által meghatározott kritériumok rendszere. ${ }^{77}$

A vitaanyagban felvetett megoldási lehetöségeket többségében nem támogatták. A Bizottságnak a támogatás visszafizetésére irányuló javaslatát például többen nehezen végrehajthatónak, éppen ezért mellőzendőnek bélyegezték. ${ }^{78}$

Voltak ugyanakkor olyan nemzeti hatóságok is, amelyek osztották a Bizottság kételyeit a jelenlegi feltételekkel kapcsolatban. A bajor filmtámogatási alap úgy vélte, hogy a tagállamok által felállított ún. „kulturális tesztek”79 alkalmatlanok a feladat ellátására, a kulturális tartalom biztosítására. ${ }^{80}$ Egyes tagállamok a versengő kedvezmények negatív hatásait is érzékelték, és támogathatónak látták ennek korlátozását. A finn hatóságok konkrétan írtak a támogatási verseny számukra negatív hatásáról is, vagyis egyes filmprodukciók más, kedvezményeket biztosító tagállamokba történő áttelepüléséröl, egyúttal jelezve, hogy az ún. kulturális teszt egyes tagállamokban nem alkalmas eszköze a valódi értékelésnek. A támogatások célkitűzéseinek változását, a gazdasági célok előtérbe kerülését a norvég hatóságok is megerősítették. A norvég hatóságok hozzászólásukban jelezték, hogy érzékelik az adókedvezmények rendszerének egyre erősödő használatát, valamint az olyan helyi támogatási kedvezmények meglétét, amelyeket gyakran inkább ipari, semmint kulturális célok motiválnak. Ezért tehát egyszerü, világos, átlátható szabályokat várnának arra nézve, hogy mely támogatások nem tekinthetők a Filmmüvészeti Közlemény alapján a belső piaccal összeegyeztethetőnek. A válasz azt is hangsúlyozta, hogy Norvégiában nincs, és nem is terveznek filmes adókedvezményt, bár egyre nagyobb a kormányra nehezedő nyomás ebben a kérdésben. Véleményük szerint mindenképpen

77 European Convention on Cinematographic Co-production, Council of Europe, 1992.

78 Belga Flamand Közösség, Franciaország, Németország.

79 A kulturális teszt hivatott biztosítani a film kulturális jellegét; ezért a támogathatóság feltétele egy kulturális szempontrendszerhez kötött pontozásos rendszerben az előírt minimális pontszám megszerzése.

80 FilmFernsehFonds Bayern Gmbh., 5. 
szükséges felső korlátokat bevezetni a támogatási verseny megfékezése céljából, amely igazodhat például a teljes költségvetés bizonyos hányadához, vagy az országban elköltött összeg bizonyos hányadához is. Fontos volt szerintük továbbá az is, hogy legyen közmegegyezés abban a kérdésben, hogyan strukturálható egy ilyen adókedvezmény-csomag ahhoz, hogy a Bizottság azt elfogadja.

A piaci szereplök - nagyobbrészt filmszakmai cégek és szervezetek - többsége szintén kiemelte a filmgyártási helyszínek versengésének nemzetközi meghatározottságát, és a filmes nagyprodukciók támogatásának elönyeit hangsúlyozta. A nemzeti hatóságok által felsoroltakon túlmenően kiemelték például, hogy a külföldi produkciók szükségesek a filmszakmai háttér fenntartásához. Egyes hozzászólók szerint a hazai produkciók, európai koprodukciók önmagukban nem nyújtanak elegendő munkalehetőséget, így a folyamatosságot, a jól képzett filmes szakembergárda megtartását, valamint a hatékony stúdiókihasználtságot is szolgálja egy-egy nagyprodukció adott tagállamba vonzása. Véleményük szerint csak ez biztosítja azt a kritikus tömeget, amely a szakemberek folyamatos képzését, foglalkoztatását, országban tartását eredményezi; és ugyancsak elengedhetetlen ahhoz, hogy az alacsony nyereséget vagy megtérülést nem biztosító filmek létrehozásához szükséges technikai és humán kapacitás Európában fennmaradjon. Több vélemény is kiemelte a támogatások járulékos pozitív hatásait, hogy a kedvezmények által valamelyik tagállamba csábított nagyprodukciónak multiplikátor hatása van, azaz megjelenik a helyi hotelszolgáltatásra, étkeztetésre, szállításra költött összegekben, áttételesen tehát testet ölt az ebböl érkező adóbevételekben, valamint hatással van a turizmusra is. ${ }^{81}$ Más, elsősorban német vélemények között az a meggyőződés is helyet kapott, hogy ezek nélkül a kedvezmények nélkül az európai piacokat még inkább az amerikai filmipar termékei uralnák. A kérdést megfordítva úgy kellene szemlélni a problémát, hogy vajon az európai filmgyártás megengedheti-e magának a nagyprodukciók elvesztését. Emellett a piaci szereplők közül többen hiányolták a Bizottság álláspontjának tényekkel való alátámasztását, azazhogy a tagállamok közötti versenyre valóban negatív hatással bírnának a tagállami támogatások közötti eltérések. ${ }^{82}$ Egyes vélemények azt is kiemelték, hogy a tagállamok közötti verseny e téren - tekintettel az országok között fennálló munkaerö-költségbeli és a munkavégzés szabályozásában fennálló eltérésekre - eleve nem egyenlő feltételeken nyugszik. ${ }^{83}$

A piaci szereplök válaszai között ugyanakkor konstruktív kezdeményezések is helyet kaptak. Többen javasolták e körben összehasonlító tanulmányok készítését, valamint ún. legjobb gyakorlati alkalmazások („,best practices”) azonosítását. ${ }^{84}$ Olyanok is voltak, akik - reflektálva a bizottság által a vitaanyagban felvázolt javaslatokra - szívesen látnák annak részleteit, vagy érdemesnek tartották e javaslat(ok) továbbgondolását. ${ }^{85}$

81 Erre egyedül Litvánia szolgál konkrétumokkal, számokkal bemutatva ennek rövid távú hatását.

82 BECTU (UK), Independent Film and Television Alliance (London), Finnish Film Distributors' Association, EuroFia (Bruxelles), FNDF (France), UK Film Distributors' Association.

83100 Autori.

84 EuroFia (Bruxelles), FERA (Brussels), Finnish Film Distributors' Association, FNDF (France), Independent Film and Television Alliance (London).

85 Cine-Regio (Aarhus), FERA (Brussels), FISA (Austria). 
A Filmművészeti Közlemény szabályainak újragondolásával kapcsolatban olyan javaslatok is születtek, amelyek az európai és nem európai filmek támogatási szempontjainak elválasztását támogatnák. ${ }^{86} \mathrm{E}$ hozzászólások szerint az első esetben egyértelműen a kulturális kritériumok meglétére hagyatkozva ítélhető meg a támogatás uniós szabályokkal való összeegyeztethetősége. A nem európai filmek tekintetében ugyanakkor elfogadnák az eltérő szabályok létjogosultságát, hangsúlyozva, hogy ügyelni kell arra, hogy Európa a globális versenyben is megállhassa a helyét. Olyan vélemény is volt, amely a tagállamok számára egységesen határozná meg a külföldi filmek támogatására fordítható összeget, és csak az Audiovizuális médiaszolgáltatásokról szóló irányelv ${ }^{87}$ alapján európai műnek minősülő filmek támogatását tenné lehetővé. ${ }^{88}$

A globális verseny kontextusában javasol megoldást a filmgyártáshoz kapcsolódó technikai szolgáltatásokat nyújtó vállalatok német szövetsége. Javaslatuk, hogy a következő WTO-tárgyalások keretében az Európai Bizottság vesse fel a nemzetközi korlátozás lehetőségét, ugyanis egy egyoldalú európai gesztus csak az európai filmipar térvesztését jelenthetné a globális versenyben. ${ }^{89}$

A nyilvános konzultáció egyik legfontosabb tanulsága a filmtámogatások szabályozásának nemzetközi meghatározottsága. A hozzászólók jelentős része a támogatási intézkedések korlátozását sérelmesnek tartaná az európai filmipar versenyképességére nézve. Kevés olyan hozzászólás született ugyanakkor, amely az amerikai Tax Foundation által felvetett kérdéseket, az adókedvezmények valós költségeit és hozamát, illetve hosszú távú gazdasági hatását tárgyalná.

\subsection{A 2013-as Filmmüvészeti Közlemény föbb szabályai}

Több mint kétéves konzultációs periódus lezárásaként került sor 2013. november 15-én az új Filmművészeti Közlemény kihirdetésére. ${ }^{90} \mathrm{~A}$ válaszok alapján elöre látható volt, hogy a Bizottság kitűzött célja, azaz a Filmművészeti Közlemény érdemi felülvizsgálata, az adókedvezményekben rejlö verseny visszaszorítása kevés eredménnyel zárulhat majd. Figyelemmel az európai audiovizuális szektor nemzetközi életképességének és versenyképességének megőrzésére, az uniós tagállamok filmtámogatási projektjeinek nemzetközi beágyazottsága olyan gazdasági érvnek bizonyult, amely az uniós szabályozás alappilléreit lényegileg nem változtathatta meg.

Lényeges újitás azonban, hogy a támogatható tevékenységek körét a Közlemény kiterjeszti a filmkészítés összes szakaszára: a forgatókönyv-fejlesztésre, a film for-

${ }^{86}$ EUROCINEMA (Bruxelles), EuroFia (Bruxelles).

87 Az Európai Parlament és a Tanács 2010/13/EU irányelve a tagállamok audiovizuális médiaszolgáltatások nyújtására vonatkozó egyes törvényi, rendeleti vagy közigazgatási rendelkezéseinek összehangolásáról (Audiovizuális médiaszolgáltatásokról szóló irányelv). HL L 95, 2010. 04. 15., 1-24.

${ }_{88}$ Caviar Films (Belgium).

89 VTFF Deutschland.

90 A Bizottság Közleménye a filmekhez és egyéb audiovizuális alkotásokhoz nyújtott állami támogatásról HL C 332, 15/11/2013, 1-11. [a továbbiakban: Filmmüvészeti Közlemény (2013)]. 
galmazására és promóciójára is. ${ }^{91}$ Rögzíti ugyanakkor, hogy a (video)játékprogramokhoz nyújtott támogatásokra a Közlemény szabályai nem terjednek ki, így azokat - szükség esetén - továbbra is egyedileg kell megítélni. ${ }^{92}$

Az új Filmmüvészeti Közlemény emellett hangsúlyozza az európai filmek gyűjtésével, megőrzésével és hozzáférhetőségével kapcsolatos mozgókép-örökségi célok fontosságát. A tagállamoknak ösztönözniük és támogatniuk kell a filmgyártókat, hogy helyezzék letétbe a támogatott művek egy-egy példányát, megőrzés és nem kereskedelmi célú hasznosítás érdekében. ${ }^{93}$

A támogatás összeegyeztetésének értékelésekor a Bizottságnak először az általános jogszerüség elvének tiszteletben tartását kell ellenőriznie, azazhogy a javasolt támogatási program biztosítja-e az EUMSZ-ben rögzített alábbi elvek tiszteletben tartását: az állampolgárság alapján történő megkülönböztetés tilalma, az áruk szabad mozgása, a munkavállalók szabad mozgása, a letelepedés szabadsága, a szolgáltatásnyújtás szabadsága, valamint a tőke szabad mozgása. ${ }^{94}$

Ezt követően kerülhet sor a specifikus értékelési szempontokra, amelyek az alábbi legfontosabb követelményeket rögzítik:

- Kulturális célkitüzés, azaz a tagállamoknak biztosítaniuk kell, hogy a támogatott termék a saját tagállami kritériumokkal összhangban kulturális tartalommal rendelkezzék. Ez megvalósulhat zsüri által történő kiválasztással, vagy egy rögzített kulturális szempontrendszer ${ }^{95}$ szerint történő értékeléssel, amellyel minden audiovizuális művet értékelnek. ${ }^{96}$

- A támogatási intenzitás ${ }^{97}$ azt fejezi ki, hogy a teljes projektköltségvetés hányadrészét teheti ki a támogatási összeg. Alapszabály szerint az állam által nyújtott támogatást a filmgyártási költségvetés 50\%-ára kell korlátozni. Kivételt képeznek ez alól a nehéz audiovizuális filmalkotások ${ }^{98}$ és fejlesztési segélyre jogosult országok részvételével készült filmek, ${ }^{99}$ ahol a támogatási intenzitás mértéke akár az elszámolható költségek $100 \%$-a is lehet. Az egynél több tagállam által finanszírozott koprodukciók esetében az intenzitás mértéke az elszámolható költségek 60\%-ára növelhető.

- A forgatókönyvíráshoz és fejlesztéshez nyújtott támogatás elvben nem korlátozott, de a projekt megvalósulása esetében beleszámít a gyártási költségekbe, így pedig a támogatási intenzitás számításánál is kalkulálni kell vele. ${ }^{100}$

91 Filmművészeti Közlemény (2013), 21. bekezdés.

92 Filmművészeti Közlemény (2013), 24. bekezdés.

93 Filmművészeti Közlemény (2013), 4.6., 43-46. bekezdések és 52. bekezdés 6. pont.

94 Az EUMSZ 18., 34., 36., 45., 49., 54., 56. és 63. cikkei; Filmművészeti Közlemény (2013), 48. bekezdés.

95 Ez az a „kulturális teszt”, amely sokak szerint eddig sem érte el a célját, ugyanakkor megpróbálja objektív pontokkal mérhetővé tenni a kulturális tartalmat.

96 Filmművészeti Közlemény (2013), 52. bekezdés 1. pont.

97 Filmművészeti Közlemény (2013), 52. bekezdés 2. pont.

98 Nehéznek minősülnek a rövidfilmek, az első és második filmes rendezők filmjei, a dokumentumfilmek, illetve az alacsony költségvetésü vagy egyébként nehezen forgalmazható művek. A szubszidiaritás elve értelmében a tagállamoknak kell megállapítaniuk a nehezen forgalmazható müvek meghatározását a nemzeti paramétereknek megfelelően.

99 Az OECD Fejlesztési Támogatási Bizottságának listáján szereplő országok.

100 Filmművészeti Közlemény (2013), 52. bekezdés 3. pont. 
- A territorializáció ${ }^{101}$ hivatott biztosítani azt a gazdasági érdeket, amely a támogatást nyújtó tagállam és az adott tagállamban realizált pénzköltés között van. Az országok kétféleképpen írhatják elő a területükön történő felhasználás mértékét: vagy úgy, hogy a nyújtott támogatási összeg legfeljebb $160 \%$-ának a támogatást nyújtó állam területén való elköltését írják elö; ${ }^{102}$ vagy a támogatási összeget kötik a támogatást nyújtó tagállamban filmkészítési tevékenységre fordított kiadás meghatározott százalékához. ${ }^{103}$ Mindkét esetben meghatározhatják a tagállam területén folytatandó filmkészítési tevékenység minimális szintjét, ami azonban nem haladhatja meg a teljes filmgyártási tevékenység $50 \%$-át. A támogatás területhez kötése a teljes filmgyártási költségvetés maximum $80 \%$-áig terjedhet. ${ }^{104}$

- A speciális kiegészitő támogatások tilalma, azaz egyes filmgyártási szakaszok támogatásának tilalma nem vonatkozik a fentebb már említett forgatókönyvírás, fejlesztés, forgalmazás és promóció támogatására, azonban ezeken túl a támogatást a gyártási lánc egyes elemeire fenntartani, például utómunkálatokra, nem lehet. Ezekre támogatáskiegészítés nem nyújtható, ezáltal tehát meghatározott munkafolyamatokat az adott tagállamba vonzani nem lehetséges. ${ }^{105}$

- A támogatást átlátható módon kell odaítélni, ennek garanciájaként legalább bizonyos információk egy lapon való közzétételét kötelezővé teszi a Közlemény. ${ }^{106}$

Az új Filmművészeti Közlemény - részben a megszületett kompromisszum idöbeni konzerválásának céljával, részben a jogbiztonság követelményét figyelembe véve - saját alkalmazhatóságát időben nem limitálta.

A Bizottság a fentieken túl az ún. általános csoportmentességi rendeletben határozza meg azokat a területeket és támogatási limiteket, ahol és amilyen mértékben a tagállamok jogosultak állami támogatást nyújtani, úgy, hogy az nincs a Bizottság előzetes jóváhagyásához kötve. A 2014-es új csoportmentességi rendelet ${ }^{107}$ bővíti a támogatási lehetőségeket, bizonyos esetekben emeli a támogatás mértékét. Hatálybalépésével, azaz 2014. július 1-jével idetartoznak a kultúrát és a kulturális örökség megőrzését előmozdító támogatások is. ${ }^{108}$

A Csoportmentességi rendelet 11. szakasza kettébontja a kulturális támogatások típusait: az 53. cikkben foglalkozik a kultúrát és a kultúra megőrzését előmozdító támogatásokkal, míg az 54. cikk szól az audiovizuális alkotásokra vonatkozó támoga-

01 Filmművészeti Közlemény (2013), 50. pont.

102 Általában direkt támogatások esetében alkalmazzák ezt a típusú megkötést.

103 Jellemzően az adókedvezmény formájában megvalósuló programok esetében alkalmazzák.

104 ZaCHAR Balázs: Filmtámogatás az Európai Bizottság szemüvegén keresztül. Állami Támogatások Joga, 2013/4, 115-126.

105 Filmművészeti Közlemény (2013), 52. bekezdés 5. pont.

106 Ennek részleteiről lásd a Filmművészeti Közlemény (2013), 52. bekezdés 7. pontját.

107 A Bizottság 651/2014/EU rendelete (2014. június 17.) a Szerződés 107. és 108. cikke alkalmazásában bizonyos támogatási kategóriáknak a belső piaccal összeegyeztethetővé nyilvánításáról. HL L 187, 2014. 06. 26., 1-78. [a továbbiakban: Csoportmentességi rendelet (2014)].

108 Csoportmentességi rendelet (2014) 1. cikk (1) j) pontja; ugyanakkor nem minden kultúrát támogató intézkedés tartozik ide, hiszen az EUMSZ 107. cikk (1) bekezdésében rögzített állami támogatás fogalmi kritériumait teljesíteni kell a támogatási intézkedésnek ahhoz, hogy az állami támogatásnak minősüljön. 
tási programok bejelentési kötelezettség alóli mentességének feltételeiről. Ez utóbbi szerint az olyan állami filmtámogatási programok bejelentése, amelyek éves költségvetése nem haladja meg az 50 millió eurót, ${ }^{109}$ és megfelelnek az 54. cikkben rögzített feltételeknek, a Bizottság felé már nem kötelező.

\section{Zárógondolatok}

Az audiovizuális alkotások szerepe az európai sokszínűség és identitások megőrzésében vitathatatlan, csakúgy, mint az ebből következő tény, nevezetesen, hogy az elkészült alkotások nyelvi, kulturális adottságaik révén általában csak korlátozottan forgalmazhatóak. Az audiovizuális alkotások közül is elsősorban a filmek gyártási költségei kiemelkedően magasak, míg azok megtérülése, a piacok fragmentáltsága révén, bizonytalan, így nehéz lenne csupán kereskedelmi forrásokból előteremteni a filmgyártási költségeket. Ezért elfogadott tény, hogy az európai filmgyártás fenntartásában kiemelkedő szerepet kapnak a nemzeti, illetve regionális filmtámogatási programok. Az Egyesült Államokkal szemben azonban az Európai Unió tagállamai nem dönthetnek korlátozás nélkül állami támogatások bevezetéséröl. Az európai uniós jogrend egyik sajátossága a tagállamok által nyújtott támogatások Európai Bizottság általi ellenőrzése, amelyet gazdaságpolitikai, integrációs és versenypolitikai célok egyaránt indokolttá tesznek.

Az Európai Unió szabályai a filmgyártás területén az EUMSZ állami támogatásokat szabályozó cikkeiben, illetve az Európai Bizottság Filmművészeti Közleményében szerepelnek. A Filmművészeti Közlemény felülvizsgálatának folyamata, annak részeként elsősorban a nyilvános konzultáció az európai audiovizuális szektor nemzetközi meghatározottságát domborította ki.

Az európai audiovizuális szektor globális élet- és versenyképességének megőrzése dominálta a diskurzust, a hozzászólók jelentős része a támogatási intézkedések korlátozását sérelmesnek tartotta az európai filmipar jövőjére nézve. Végül az új Filmművészeti Közlemény a tagállami akaratok érvényesülését hozta, figyelemmel az európai audiovizuális szektor nemzetközi életképességének és versenyképességének megőrzésére - eredeti céljával ellentétben -, a tervezett szigorító jellegü szabályokról a Bizottság lemondani kényszerült. Az új közlemény szabályainak ismertetése a régi, legfontosabb követelmények strukturális ismertetése mentén is lehetséges volt, hiszen annak jelentős változásairól nem adhattam számot.

Legföbb újitása az új Filmművészeti Közleménynek a támogatható tevékenységek körének bővítése, valamint a mozgókép-örökségi célok hangsúlyossá tétele. Elsikkadtak olyan kritikai felvetések, amelyek az adókedvezmények valós költségeit és hozamát, hosszú távú gazdasági hatását, illetve a belső piacra negatívan ható gazdasági támogatási harc meglétét érintik. Nem meglepő e szabályozás gyakorlatot érintő hatása az Európai Unión belül. A tény az, hogy a filmtámogatási rendszerek az Európai Unió tagállamainak többségében léteznek, virágzanak, mindössze-

109 Csoportmentességi rendelet (2014) 4. cikk (1) aa). 
sen három tagállamban (Görögország, Portugália és Románia) ${ }^{110}$ nincs érvényben filmtámogatási rendszer.

Tekintettel a globális verseny várható további éleződésére, amelyet jól illusztrál az új, elsősorban ázsiai országok bekapcsolódása ebbe a versenybe, az a javaslat, hogy a következő WTO-tárgyalások keretében az Európai Bizottság vesse fel a nemzetközi korlátozás lehetőségét, nem tűnik életszerünek. A gazdasági dominanciáert vívott harc egyben kulturális dominanciáért vívott harc, így még az utóbbi évek világgazdasági válsága sem tudta azon alternatívák felé billenteni a közgazdasági racionalitás mérlegét, amelyek finanszírozásáról az állam a filmtámogatás javára lemondani kényszerül.

\section{Abstract}

The current article aims at mapping the origins of film aid schemes, comparing the different motives that lay behind the American and European model eventually leading to a globally strengthening subsidy race. Rules guiding national subsidies for the film industry in the European Union have their limits in the State Aid rules of the Treaty on the Functioning of the European Union as well as the Communication of the Commission on certain legal aspects relating to cinematographic and other audiovisual works.

110 State aid N 303/10 - Romania - Romanian film support scheme; 2014. december 31-én járt le. 